\title{
DIE KORPS „VERITAS VINCET” EN SY VERBAND MET DIE TEOLOGIESE SKOOL.
}

Korps V.V. was nie die eerste studente-vereniging aan die Teologiese Skool nie. Ander het hom naamlik voorafgegaan bv. die „StudenteLetterkundige-Vereniging (in 1892 gestig). Dat Korps V.V. egter vandag nog bestaan en ook reeds sy vyftigjarige bestaan kon vier, is getuienis dat sy stigting lewensvatbaarheid gehad het en dat sy beginsels suiwer is.

Op 18 Mei 1894 het die studente van die hoëre klasse van die T.S., na voorafgaande samekomste, weereens vergader en besluit om op 1 Junie bymekaar te kom om hulself om te vorm tot 'n „Corps." Hulle gaan dan oor tot die konstituering van „Het Gereformeerde Studenten Corps, onder de zinspreuk: :,Veritas Vincet," met 'n totale ledetal van 5. Ds. J. A. v. Rooy (stigter en eerste Voors.) in sy boodskap aan Korps met die Fees in 1944 sê: „Dit (die stigting) het sy oorsaak in en staan in verband met algemene omstandighede en besondere gebeurtenisse van daardie tyd; meer bepaald wat betref ons studentelewe en sosiale omgang, in nou verband met ons Skool en Kerk se belange; met doelstelling: eenswording, saambinding, onderlinge vorming, goeie verstandhouding, hartlike vertroue; om op mekaar te kan reken vir saamstaan en medewerking by toekomstige optrede tot vervulling van die Goddelike lewensroeping.' Sy Eerw. beskryf die algemene gees van sy tyd as 'n ,smoorslaap van uit. heemsnaäperige, soeterig-metodistiese onnasionalisme" en hierdie stigting as deel van 'n frisse, varse gees van selfbewuste Afrikanerskap. Daar het Korps sy intrede gemaak in die lewe van die Skool-met 'n doelstelling om Gereformeerde beginsels aan te kweek en voort te plant op godsdienstige en staatkundige gebied-en dit het veral van daadwerklike betekenis gebly tot die skeiding van die T.S. en die P.U.K. (1920). Dit is ook vernaamlik wat in die stuk betrag word.

Soos blyk uit die stigting van Korps het dit in noue betrekking gestaan tot die hele Skoollewe. Dié karakter het hy dan ook deurgaans bewaar. Jaarliks is met die sitting van die Kuratore 'n jaarvergadering gehou, waartoe die erelede uitgenooi is. Dan is ' $n$ onderwerp voorgedra deur 
cen van die Kuratore of een van die lede en daarna het gewoonlik interessante bespreking gevolg. Die doel van die vergadering was om die gedane werk na te gaan en om die Kuratore te ontmoet, sodat hulle meteen kan sien wat deur die studente gedoen word. Verdere getuienis hiervoor is dat ' $n$ versoek deur die Senaat aan Korps gerig word (10 November 1916) om ook geld in te samel vir die Jubileumfonds; hulle moet veral werk onder studente en oud-studente. In die vroeëre jare is ook steeds stukke geskryf deur lede van Korps wat in die "Maandbode" en later in die „Kerkblad” gepubliseer is. Na die onderbreking van Korps se werksaamhede tydens die Goudoorlog is hierdie gebruik egter gestaak.

Die temas in die blaaie behandel, was meesal lesings voor Korps gehou. Gaan ons die onderwerpe na waaroor in Korpsvergaderings gehandel is, dan sal daar van die allerverskeidenste aangetref word. In die besproke problem meen ons 'n spieëlbeeld te sien van die algemene gang van belangstelling van die studente van die respektiewe tye. Interessant is dan ook die miskien gewaagde stelling dat dit ons meteen die algemene belangstelling van die tyd en meer spesifiek van ons voorgangers op die Skool kenskets. Hiérdie temas is spesiaal aangepak en behandel en nie ander nie. Die notuleboek van Korps kan dan ook so vir ons 'n beeld gee van die sake wat besondere aandag geniet het. Ons noem 'n paar: 28 Sept. 1894--J. A. van Rooy oor:: „Is het behoud van onze taal van belang voor de Gereformeerde Gezindheid"?; 16 Okt. 1896-P. Snyman: "Taalkwestie in Zuid-Afrika"; 17 Sept. 1897: J. D. du Toit: „Is de Kerk verantwoordelijk voor de Wetenschappelijke opleiding harer Dienaren"? 23 Okt. 1908: C. van Rooy: „Kerk en Staat.” Van belang ook in die behandeling van die onderwerpe is dat bronne wat geraadpleeg word, name is soos Witsius, Kuyper, Bavinck. Dit toon vir ons egter ook dat die studente hulself nie alleen in die studiesaal wou bekwaam en hul beginselgrondslag vaslê nie, maar ook onder hulself die sake wou ondersoek en verantwoording doen van hul opvatting. Manne van naam is dan ook vandag oud-lede van Korps.

Die primêre doel van Korps was om as vereniging studie-werksaamheid te doen. Die verwesenliking van sy doestelling (vgl. hierbo) was gerig op: (a) hoofsaaklik im eie kring; (b) in gehele studentekring; (c) in soverre dit pas en moontlik is na buite. Hieroor val nou in tweërlei sin te spreek: eerstens of dit sy plig in enger kring nagekom het en tweedens in breër kring. Aanvanklik was Korps net studievereniging-daarom ook die eis dat sy lede reeds matrikulasie moes afgelê het--maar met die uitbreiding van die gêtalle van die studente neem ook sy werksaamhede toe. En in 1914 kom daar verandering deurdat gese word: „Dit Corps stelt zich 
ten doel voor zijn deel: (a) orgaan te zijn van de studentenwereld aan de Theologische School; (b) zijn leden te vormen voor hun toekomstige loopbaan." 28 Maart, 1914). Dit wil dus sê dat Korps nie meer 'n blote vereniging is nie, maar 'n studenteverteenwoordigende liggaam. Dit gaan eers nie deur nie, maar nadat die Matriekklas afgeskei is in 1916 en by die Voorbereidende Departement (nou Potcheîstroomse Gimnasium) gevoeg is, tree Korps op as die offisiële studentevereniging. As sodanig word dit ook deur die Senaat erken (6 Mei 1916). Later word nog ' $n$ funksie bygevoeg deurdat Korps 'n tak word van die A.S.B. (Afrik. Studentebondlater A.N.S.). Allerlei funksies moet nou deur Korps verrig word-o.a. die vasstelling van kleure, ontgroeningsake en daarby gee hulle nog dic blad "Veritas Vincet" uit. Dis te veel en die eintlike Korpswerksaamhede begin skade ly. In 1918 word 'n aparte A.S.B.-tak gestig. Dan kom die inkorporasie van die P.U.K. en die skeiding van die twee inrigtings, wat ook weer moeilikhede meebring.

Korpsbestuur is eers S.V.R., later word daarby gevoeg die praetores van die P.U.K. en T.S., maar in 1924 word die S.V.R. apart gekies en Korps keer weer terug tot sy ou bestaan soos in die jare 1894-... 1914. Daarmee hou Korps op on offisiële liggaa'n van die Teologiesc studente te wees, wat dit tog in sekere sin was vanaf 1894. Korps gaan voort met sy werksaamhede, maar sy direkte verband met die Skool is hiermee ook ten einde. Tog staan dit vandag nog in sy Konstitusie: „daar bestaan aan die P.U.K. vir C.H.O. en Teologiese Skool . . . . 'n Gereformeerde Studentekorps." Nog dien Korps om die studente te bekwaam en beginselgrondslag te gee.

Korps het egtar ook 'n taak in breër kring gehad, wat miskien nie so direk met die T.S. saamhang nic, maar tog genoem moet word, aangesien dit toon hoe die studente hul wyere taak ook ingesien het. Sy vormende invloed op die P.U.K. wil ons deur twee voorbeelde stel: Op 26 Febr. 1904 spreek prof. F. Postma Korps toe oor s.g. ideae innatae (aangebore ideë) en sê dan o.a. dat die siel geen aangebore kennis het nie, omdat alleen „In Uw licht zien wij het licht." En die kleure van die P.U.K. is die kleure van Korps. Sy roeping teenoor ons taal het Korps besef. Op 16 Okt. 1896 lewer J. D. du Toit ' $n$ ' lesing oor: „De Bybelvertaling in 't Afrikaansch" en hy beskou dit as wenslik en noodsaaklik. En op 27 Februarie 1915 vra die Voors. die vergadering goedkeuring vir die Komiteebesluit: Mnr. L. J. du Plessis 'n kans te geven zijn werk in 't Afrikaans te leveren, en de bespreking ook in Afrikaans te doen toegaan-dis algemeen aangeneem en 'n lesing word gelewer oor: „Digter en natuur in S.A." Daarna is Afrikaans ook erken as die offlsiële tałal van Korps. Tor die jong Afrikaners in die Suide begin organiseer het in die Werda- 
komitee was Korps ook by-'n afgevaardigde is gestuur na die Heldedagviering te Stellenbosch in begin 1916 en later is 'n kommissie gekies wat sake vanuit Korps hier in Transvaal moes organiseer vir Werda-komitees. Die lede hiervan was: C. W. M. du Toit, D. J. v. Rooy en J. C. v. Rooy. So is die A.S.B. gestig. Maar ook om ons Calvinistiese beginsels die volkslewe in te dra het Korps sy werk gedoen: steeds het hy gepropageer vir die christelike karakter van ons skole, vir C.N.O., daar is ajo in 1907 ondersoek ingestel na die stigting van 'n Calvinistiese Bond en in 1927 word gespreek oor die moontlike oprigting van 'n Calvinistiese Pers. En Korps het ook later meegewerk aan die F.C.S.V.-publikasies-dink maar net aan die stel „Koers-in-die-Krisis." Meer getuienis is onnodig.

Korps het 'n taak gehad in en aan die Teologiese Skool (later is P.U.K. vir C.H.O. by) en dit het hy vervul. Saam met die Skool het hy gegroei, gely en gestry. Maar alleen met die leuse: Veritas Vincet!

Potchefstroom.

DION. KEMPFF. 